\title{
6,700-year sedimentary record of climatic and anthropogenic signals in Lake Aydat (French Massif Central)
}

Marlène Lavrieux ${ }^{\mathrm{a} b, *}$, Jean-Robert Disnar ${ }^{\mathrm{a}}$, Emmanuel Chapron $^{\mathrm{a}}$, Jean-Gabriel Bréheret ${ }^{\mathrm{b}}$, Jérémy Jacob ${ }^{\mathrm{a}}$, Yannick Miras ${ }^{\mathrm{c}, \mathrm{d}}$, Jean-Louis Reyss ${ }^{\mathrm{e}}$, Valérie Andrieu-Ponel, Fabien Arnaud ${ }^{\mathrm{f}}$.

${ }^{a}$ Institut des Sciences de la Terre d'Orléans, Université d'Orléans, ISTO, UMR 7327, 45071, Orléans, France ; CNRS/INSU, ISTO, UMR 7327, 45071 Orléans, France ; BRGM, ISTO, UMR 7327, BP 36009, 45060 Orléans, France.

${ }^{\mathrm{b}}$ GéHCo (GéoHydrosystèmes Continentaux), EA 6293, Faculté des Sciences et Techniques, Université François-Rabelais de Tours, Parc Grandmont, 37200 Tours, France.

${ }^{\mathrm{c}}$ CNRS, GEOLAB, UMR 6042, Laboratoire de Géographique physique et environnementale, 4 rue Ledru, 63057 Clermont-Ferrand Cedex 1, France.

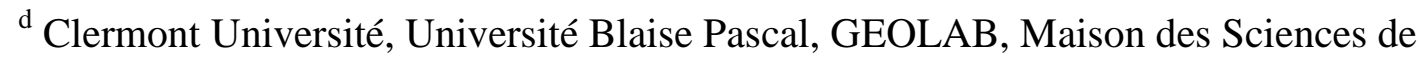
l’Homme, BP 10448, 63000 Clermont-Ferrand, France.

${ }^{\text {e }}$ Laboratoire des Sciences du Climat et de l'Environnement, UMR 8212, UVSQ/CNRS/CEA, Domaine du CNRS, 91198 Gif-sur-Yvette, France.

${ }^{\mathrm{f}}$ Institut Méditerranéen d'Ecologie et de Paléoécologie, UMR CNRS 6116 Université Paul Cézanne, Bâtiment Villemin, BP 80, 13545 Aix en Provence Cedex 04, France.

${ }^{g}$ Environnements, Dynamiques et Territoires de la Montagne, UMR 5204, Université de Savoie, CNRS, CISM, Campus Scientifique, 73376 Le Bourget du Lac Cedex, France.

*: corresponding author - M. Lavrieux. Current address: Laboratoire des Sciences du Climat et de l'Environnement, CEA - Orme des Merisiers, F-91191 Gif-sur-Yvette Cedex, marlene.lavrieux@univ-fcomte.fr.

\section{Abstract (233 words)}

A 19-meter-long sedimentary record retrieved in Lake Aydat (French Massif Central) covers the last $6700 \mathrm{yrs}$ at a high-resolution. A multi-proxy approach (density, magnetic susceptibility, XRF, Rock-Eval, pollen and non-pollen palynomorph analyses and a historical archives study) was used to characterise and propose a model of sedimentation. The high 
deposition rate results from the combined effects of the high suspension load of the river, autochthonous production and the narrow shape of the incised fluvial valley dammed by a lava flow ca. 8550 years ago. Two contrasted periods $(6700 \pm 200-3180 \pm 90 \mathrm{cal}$. BP, and 1770 \pm 60 cal. BP- now) were characterized. The lower unit (mid-Holocene) displays a fine and regular lamination and holds a single, major, flood deposit. This unit is capped by an erosive mass wasting deposit triggered ca. $1770 \pm 60 \mathrm{cal}$. BP. The upper unit (late-Holocene) is made of organic rich and fine grained faintly laminated sediment, with numerous interbedded flood deposits and diatom blooms. The sedimentation was principally controlled by climatic forcings until ca. $1100 \mathrm{cal}$. BP, accompanied by detrital events linked to human activities around the lake. Then, a more detrital input attested by numerous and recurrent flood deposits can be linked to the intensification of a persistent anthropogenic impact on the catchment. Two phases of lake eutrophication are highlighted: 1200-1130 cal. BP, as a result of increased anthropogenic pressure, and the current phase that could have started ca. $150 \mathrm{cal}$. BP. Keywords: Lake sediments, French Massif Central, Detrital input, Climate, Anthropogenic activities, Holocene 


\section{Introduction}

Anthropogenic activities are now universally considered as having a strong impact on natural systems (e.g. Dearing, 2006) and on the whole terrestrial environment (IPCC, 2007), including geological processes (e.g. Crutzen, 2002; Wilkinson, 2005). It is therefore crucial to comprehend the complex inter-relationships linking societies, climate and environments. Unravelling such interactions entails studying natural records, which provide information that allows the consequences of current global change to be anticipated (Costanza et al., 2007). Among various natural archives having a well-proven preservation potential, lacustrine sediments can provide high quality information. Like marine pelagic sediments, they generally constitute continuous records, but in contrast to the former they can deliver local information about the natural (climate, topography, vegetation...) and anthropogenic conditions prevailing at the limited spatial scale of a drainage basin (e.g. Zolitschka and Ariztegui, 2007; Battarbee and Bennion, 2011). The mid-altitude mountainous configuration of the French Massif Central, at the boundary of oceanic and continental climatic influences, confers on this region a relatively high sensitivity to climatic changes coupled with marked anthropization. However, so far, only a few studies have been devoted to the interactions between the environment, humans and climate in this region, with the notable exception of its northern plain, the Limagne (e.g. Ballut, 2000; Fourmont et al., 2009; Macaire et al., 2010). Earlier palaeoenvironmental studies performed on the mountainous part, the Chaîne des Puys, focused mainly on vegetation history and tephrostratigraphy (Beaulieu and Goeury, 1987; Juvigné et al., 1988). Multiproxy analyses on Auvergne mountain areas combining palaeoecology, archaeology and historical sources still remain scarce (e.g. Michelin et al., 2001; Miras et al., 2004; Prat, 2006; Surmely et al., 2009; Ballut et al., 2012), especially when compared to regions such as the NW Alps, where lacustrine archives are numerous and have 
been extensively studied (e.g. Chapron et al., 2002; Magny, 2004; Arnaud et al., 2005; Leroux et al., 2008; Debret et al., 2010). The Massif Central did not benefit from the same interest, although it contains a notable number of lakes, including crater lakes that are remnants of its Tertiary to Quaternary - including Holocene - volcanic activity. While the sediment infill of some of these lakes has been investigated for various purposes (e.g. to track erosion fluxes or highlight natural hazards: Macaire et al. 1995; Gay and Macaire, 1999; Chapron et al., 2010), up to now no high-resolution multidisciplinary study of a long-term lake sediment record has been conducted in this region. The history of human occupation in the surroundings of Lake Aydat has already been explored (Miras et al., 2004) and thus represents a suitable target to partly fill this gap. Moreover its recent sedimentation and (bio)chemical characteristics have recently been studied to apprehend its current eutrophic functioning (e.g. Sarazin et al., 1992, 1995; Alfonso, 2000; Stefanova and Disnar, 2000; Michard et al., 2001; Ogier et al., 2001). In this perspective, this paper reports the results of the investigations carried out on a 19 meterlong Lake Aydat sedimentary sequence that covers the last 6700 years. The establishment of an age-depth model and comparison with other studies are used to highlight climatic and anthropogenic contributions to the sedimentary signal, approached through density, magnetic susceptibility (MS), X-ray fluorescence spectrometry (XRF), organic bulk analyses, pollen and non-pollen palynomorph (NPP) analyses and a study of historical archives.

\section{General setting}

Lake Aydat (N 4539.809' / E 259.106') is located in the French Massif Central, ca. 25 km SW from Clermont-Ferrand, at the southern boundary of the Chaîne des Puys volcanic range (Figure 1), where it forms a plateau sharply incised by V-shaped valleys. The lake is at an altitude of $837 \mathrm{~m}$ a.s.l. and originates from the damming of the Veyre River by a basalt 
flow dated from $8551 \pm 400$ cal. BP that issued from the Puy de la Vache and Puy de Lassolas volcanoes (Boivin et al., 2004). The lake surface is $6.10^{5} \mathrm{~m}^{2}$. Its water volume is of ca. $5.2 .10^{6}$ $\mathrm{m}^{3}$, with an average depth of $7 \mathrm{~m}$ and a maximum depth of $15 \mathrm{~m}$. The mean residence time of waters is ca. 7.5 months (Michard et al., 2001). The lake is eutrophic and is mainly fed from the West by the Veyre River (75\%), completed by a lateral supply through the shores and direct precipitation $(25 \%)$. The river constitutes the main outlet for the waters $(85 \%)$, the rest (15\%) percolating through the basaltic flow (Bouchet, 1987). An earlier study estimated the recent (last 50 years) sedimentation rate at ca. $0.46 \mathrm{~cm} / \mathrm{yr}$ in the deepest part of the basin (Sarazin et al., 1992). The lake's catchment is located upstream the Loire River basin and is mainly fed by precipitation brought from the Atlantic Ocean depressions. Its surface is ca. 30 $\mathrm{km}^{2}$ and extends from $837 \mathrm{~m}$ a.s.l. to $1300 \mathrm{~m}$ a.s.l. (West, top of the volcanoes; Figure 1). It develops on a plutonic and metamorphic substratum (mainly granodiorites), partially covered by late glacial to Holocene volcanic deposits (Boivin et al., 2004). Nowadays, the catchment is mainly covered by grasslands and pastures, and by human-sowed secondary forests (principally coniferous: Picea sp.), mainly on the top of volcanoes. Andisols constitute the typical type of soil covering the catchment.

(Figure 1 here)

\section{$\underline{\text { 3. Material and methods }}$}

A high-resolution seismic reflection survey, carried out prior to the coring, failed to reveal the detailed structure of sedimentary deposits because of a high content of methane, but confirmed previous bathymetric measurements (Figures 2a, b). Accordingly, the coring site was chosen in the central and deepest part of the basin, close to the Veyre River delta. A continuous sequence (AYD09) was retrieved in 2- and 3- meter long sections at $14.5 \mathrm{~m}$ water 
depth (Figure 1) with a UWITEC coring platform. A set of core sections at two nearby locations allowed the recovery of a $19 \mathrm{~m}$ long sedimentary record (Figure 3), once the core sections had been opened, described and correlated based on the identification of key lithological horizons on each core section. The core was divided into 1-cm-thick slices for analytical purposes. The chronology of the top $20 \mathrm{~cm}$ of the sequence is based on ${ }^{137} \mathrm{Cs}$ and ${ }^{241}$ Am measurements (Table I; Figure 4). 25 samples from the top of the core were measured by ultra-low background, high-efficiency gamma-spectrometry at the "Laboratoire Souterrain de Modane" as described in Reyss et al. (1995). ${ }^{137}$ Cs and ${ }^{241} \mathrm{Am}$ were measured together with ${ }^{210} \mathrm{~Pb}$ and ${ }^{7} \mathrm{Be} .17 \mathrm{AMS}$ radiocarbon dates distributed over the core, based on leaf and wood fragment analyses and obtained at the Laboratoire de Mesure du Carbone 14 (Gif-sur-Yvette,

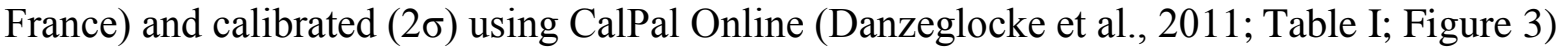
constitute the base of the whole core chronology. The scarcity of datable organic material in the top 7 meters was counterbalanced by the detection of numerous $\mathrm{mm}$ - to $\mathrm{cm}$-scale flood deposits (Mulder and Chapron, 2011) that were correlated with historically-described flood events that are well documented in the Loire River catchment and allowed validation of the age-depth model (Champion, 1858-1864; Deblaère and Fabry, 1998; Genêt, 2007; Table II; Figure 3; see 4.1 for the identification of flood deposits). Loire River floods mainly originate from its upstream part (i.e. Massif Central), as a result of numerous factors (hydrologic conditions, slopes, impermeable geology...; Genêt, 2007), so they can be reliably compared to those recorded in Lake Aydat sediments. MS and XRF-based element composition were measured following a step of $1 \mathrm{~cm}$ using a Bartington MS2E point sensor on a Geotek MultiSensor Core Logger System (MS; Chrono-Environnment, Besançon, France) and a Avaatech Core Scanner (XRF; Environnements et Paléoenvironnements Océaniques et Continentaux, Bordeaux, France), respectively. Density was appraised by continuous measurements using a Hologic densitometer (dual energy X-ray absorptiometry; Institut de Prévention et de 
Recherche sur l'Ostéoporose, Orléans, France), and SEM pictures were acquired from a LEO, Gemini, Zeiss DSM 982. Bulk organic matter (OM) analyses were carried out with a RockEval6 (RE6) on ca. $60 \mathrm{mg}$ of dried and crushed sediments. The Rock-Eval parameters used in this study are Total Organic Carbon (TOC, \%), Hydrogen Index (HI, mg hydrocarbons.g $\mathrm{TOC}^{-1}$ ), and Oxygen Index (OI, mg CO $2 . \mathrm{g} \mathrm{TOC}^{-1}$; Espitalié et al., 1985; Lafargue et al., 1998). Samples were taken every $2.5 \mathrm{~cm}$ for pollen and non-pollen palynomorph (NPP) analysis, and prepared using standard procedure (Faegri and Iversen, 1989). Minimum counts of 500 dry land pollen grains per sample were made. Pollen and NPP values were calculated as the percentage of total land pollen excluding Cyperaceae, fern spores and aquatic plants. As this article aims at dealing with Holocene sedimentation, pollen and NPP assemblages are interpreted here in broad terms with added curves presenting the Arboreal Pollen / Total Pollen (AP/T) ratio, crops, Anthropogenic Pollen Indicators (API) including pollen taxa indicative of human impact (Behre, 1981) and those underlined by the modern pollen assemblages study carried out in the Massif Central (Miras, 2009) and coprophilous fungi that are useful to assess local grazing activity (van Geel et al., 1989; Ejarque et al., 2011).

(Figure 2 and Tables I and II here)

\section{Results}

\subsection{Background sedimentation and origin of detrital inputs}

Ogier (1999) showed that sediments of the Veyre River are rich in $\mathrm{Rb}$, Ti and $\mathrm{K}$ that can thus be used as markers of detrital inputs. This characteristic is also attributable to density and MS measurements in the core that highly correlate with these three elements (Figure 3). Any increase in these physical parameters inside a rapidly deposited layer (RDL) can 
therefore be considered as resulting from an amplification of the erosion flux, and thus to hyperpycnal flood events, as expanded by Mulder and Chapron (2011). The siliceous endogenic phase is the main constituent of the background sedimentation, half of the dissolved Si that comes into the lake being finally stocked as opal A in diatom frustules (Sarazin and Devaux, 1991; Ogier, 1999).

(Figure 3 here)

\subsection{Sedimentological features}

Based on sedimentological features, the record is divided into three main units (Figures 3 and 4):

- The lower unit (1076-1914 cm depth) shows laminations consisting of alternating beige diatom blooms and dark detrital levels. Despite these two major sources the sediment is rich in OM (generally $8-10 \%$ TOC), with moderate HI and OI values (250-300 mgHC.g ${ }^{-1}$ TOC and 100-150 $\mathrm{mgO}_{2} \cdot \mathrm{g}^{-1} \mathrm{TOC}$, respectively). It also contains one major flood deposit, the thickest one of the whole core (1248-1254 cm depth). The background MS value of this unit is mostly $<10.10^{-5}$, but can reach up to $40.10^{-5}$ S.I., and is highly correlated to XRF (Ti, K) measurements. In the upper part, laminae are noticeably affected by microfaults, thus attesting to a destabilization of the sediment after deposition.

- The upper unit (0-829 $\mathrm{cm}$ depth) contrasts strongly with the lower one. It is constituted by a background of dark and faintly laminated OM rich sediment (3-5.5\% TOC) also showing moderate $\mathrm{HI}$ and OI values (200-300 mgHC.g $\mathrm{g}^{-1}$ TOC and 100-200 $\mathrm{mgO}_{2} \cdot \mathrm{g}^{-1} \mathrm{TOC}$, respectively), frequently interrupted by diatom blooms and flood deposits $(1-5 \mathrm{~cm}$ thick;

Figure 3). The latter are darker and characterized by high density and high MS (up to $800.10^{-5}$ S.I), reflecting increased erosional inputs from the catchment (§ 4.1). 
Background MS mostly ranges between 40 and $100.10^{-5}$ S.I, and shows the same trends as the $\mathrm{Rb}$, Ti and $\mathrm{K}$ ones.

- Between the two previous units (829-1076 cm depth), the correlation between the two twin cores was impossible. $1 \mathrm{~m}$ of the sedimentary sequence appeared exactly repeated in only one of the twin cores, while particular MS fluctuations were unique to the other one (this one illustrated in Figure 3). Naked eye observation allowed the distinction of disturbed layers at the boundaries. Combined with the presence of the micro-faults at the top of the lower unit, these indices were interpreted as a mass wasting deposit (MWD; Mulder and Cochonat, 1996) that reworked ca. $2.5 \mathrm{~m}$ of sediment. Consequently, this unit is not discussed further here.

(Figure 4 here)

\subsection{Depth-age model and accumulation rate}

Due to its short half-life (53 days), the detection of ${ }^{7} \mathrm{Be}$ in the uppermost layers of the core attests to a well-preserved sediment interface (Figure 4). From the artificial radionuclides profile (Table I, Figure 4; Appleby, 2000) two events were dated: (i) the 1986 AD Chernobyl accident at $16.5 \mathrm{~cm}$ depth (corrected depths, i.e. without flood events) characterized by the high activity of ${ }^{137} \mathrm{Cs}$; (ii) the $1963 \mathrm{AD}$ maximum fallout resulting from atmospheric nuclear bomb tests at $24.5 \mathrm{~cm}$ depth indicated by the high activities of both ${ }^{137} \mathrm{Cs}$ and ${ }^{241} \mathrm{Am}$. Then the recent sedimentation rate was estimated after removing a RDL individualized between these two bounds (21-22 cm depth; Table II) to establish the recent part of the depth-age model. In this chronological frame, this RDL correlates with the 1976 AD major local flood event (Deblaère and Fabry, 1998), confirming the assignation of this type of sedimentary event to flood deposits. ${ }^{210} \mathrm{~Pb}$ failed to give reliable results. Previous work carried out in the same lake 
(Sarazin et al., 1992) attributed this failure to the very low compaction of the sediment. Among the 17 AMS radiocarbon dates, 2 were excluded from the depth-age model (1 gave an aberrant age, and 1 belonged to the repeated part of the MWD). 58 RDLs (56 flood events in the upper unit, 1 flood event in the lower one, plus the MWD) were removed from the sequence prior to the establishment of the age-depth model, entailing a shortening of the considered section. Finally, the background sediment record of the upper and lower units expanded between 0-774.5 and 774.5 $-1597.5 \mathrm{~cm}$ depth, respectively. These depths are used as reference in the following discussion. The whole sequence covers the last 6730 years (Figures 3 and 4). The mean background sedimentation rate is $0.20 \mathrm{~cm} . \mathrm{yr}^{-1}$ for the lower unit, and also for the basal part of the upper unit (i.e. in the 774.5-660 $\mathrm{cm}$ depth interval). It suddenly increases to reach $0.52 \mathrm{~cm} / \mathrm{yr}$ from $660 \mathrm{~cm}$ depth up to the top. This value is close to the rate of $0.46 \mathrm{~cm} / \mathrm{yr}$ estimated by Sarazin et al. (1992) for the last 50 years, which validates the recent part of the depth-age model. The sedimentation rate reaches $0.6 \mathrm{~cm} . \mathrm{yr}^{-1}$ when flood events are considered in the calculation. A transversal altitudinal profile, deduced from the bathymetric map and extended to the slopes of the lake sides, highlights the narrow V-shaped morphology of the valley (Figure 2c). A longitudinal profile allows extrapolation of the substratum surface from two checkpoints (location of the substratum outcropping upstream the Veyre delta, and the depth at which the substratum was reached in a drilling in the basaltic flow; Auriat, 1957), in order to roughly estimate the depth of the substratum directly below the coring site of this study. The information provided by these profiles is consistent with the maximum plausible sediment accumulation at the coring site of this study (ca. $23 \mathrm{~m}$, calculated from the supposed age of the lake and the sedimentation rate). In this hypothesis, the substratum should be located at ca.780 $\mathrm{m}$ a.s.l. (Figure $2 \mathrm{~d}$ ). This indicates that the core was probably retrieved close to the deepest point of the paleovalley, where the sediment accommodation potential is maximal. The thickness of the deposits, originating from (1) the 
high suspension load of the river, especially during flood events, associated to (2) a high organic productivity in the lake (diatom blooms...), itself depending on the chemical erosion coming from the catchment (Sarazin and Devaux, 1991; Ogier, 1999; Macaire et al., 2010), is thus reinforced by the particular geometry of the lacustrine basin, which effectively constrains this clastic sediment to accumulate in the deepest part of the lake (Mulder and Chapron, 2011).

\subsection{Pollen data}

Pollen data that were obtained from background sediment samples (i.e. without flood deposits; Figures 5, 6) show that Arborean pollen are largely dominant throughout the lower unit (AP/T generally > 90\%; Figure 5). Pinus sharply decreases as Fagus increases, from ca. $5600 \mathrm{cal}$. BP. Evidence of anthropogenic activities are recorded through indices of crops and coprophilous fungi. A similar pattern is observed at the base of the upper unit (Figure 6), but crop pollen occurrences become continuous. AP/T suddenly decreases from $1500 \mathrm{cal}$. BP, when anthropogenic indicators (API) - Poaceae, crops and coprophilous fungi - increase sharply. 150 cal. BP clearly signs the renewal of Pinus, to the detriment of crops and coprophilous fungi indicators. These general trends follow those observed through physical (MS, density, XRF) and bulk geochemical (TOC, HI, OI) analyses, and allowed the recognition of different phases covering the whole lower unit, and four in the upper one (1770-1500 cal. BP, 1500-1200 cal. BP, 1200-150 cal. BP, 150 cal. BP - present).

(Figures 5 and 6 here)

\section{Discussion: climatic and anthropogenic influences on the sedimentary record}


$\mathrm{Rb}$, Ti and $\mathrm{K}$ signatures recorded in the sediments come from the erosion of andisoils, themselves deriving from a minor contribution of the granodioritic substratum added to the material originating from volcanic formations (Ogier, 1999). This detrital imprint is recorded in flood deposits, and to a lesser extent in the background sedimentation. Natural / anthropogenic contributions to the sedimentary record were evaluated by comparing the background detrital input (i.e., MS without instantaneous deposits) and pollen data with previously studied climatic and anthropogenic records, as shown in Figures 5 and 6. Local human impact was mostly estimated from pollen and NPP analyses acquired during the current study, compared to the former high-resolution palynological and multi-disciplinary study performed on the 5000-year-long record of the "Narse d'Espinasse" (Miras et al., 2004), a peat marsh located in the lake's catchment (Figure 1), that certainly constituted up to now one of the most complete palaeoenvironmental Holocene records for the whole Massif Central.

\subsection{Lower unit (6730-3200 cal. BP)}

All along this unit the OM contents appeared to remain stable both from a quantitative (TOC: $8-10 \%$ ) and qualitative point of view (HI and OI,, 250-300 mgHC.g ${ }^{-1}$ TOC and 100$150 \mathrm{mgO}_{2} \cdot \mathrm{g}^{-1} \mathrm{TOC}$, respectively). These geochemical characteristics sign an OM classically derived indistinctly from terrestrial plants (Meyers and Lallier-Vergès, 1999) and from diatoms which appear to produce rather similar HI and OI values (Ariztegui et al., 2001). Throughout this unit, 6 phases of relatively higher background detrital input are depicted on the basis of MS variations (Figure 5), in particular on long-term increasing tendencies and more short-term but highly significant increases in MS. These major features seem to coincide 
with the general pattern of the climate-driven Lake Accesa level evolution (Tuscany, NorthCentral Italy, reflecting the whole West-European pattern; Magny et al., 2007), and more generally with periods of lower solar activity (Wanner et al., 2008), the latter inducing climatic variations (with cooler and more humid conditions) considered to favour enhanced soil erosion on catchments (Arnaud et al., 2005; Debret et al., 2010). However, this comparison is not sufficient to explain the amplitude of variation of the detrital input observed at ca. 5900 cal. BP, which is much greater than the other ones in this unit, or the $3800 \mathrm{cal}$. BP increase of detrital input that is not correlated with a climatic event. Other factors must be invoked, such as human impact that can be assessed from pollen and NPP analyses (Figure 5). At ca. 6000 cal. BP, the slight decrease in the AP/T ratio, associated with an increase in herbaceous taxa and dung-related fungi, evidence the first, moderate woodland opening accompanied by local grazing activity. Together with a favorable climatic context, these putative slight human impacts likely influenced detrital inputs. The corresponding catchment occupation was most probably occasional, as pollen and NPP indices of abandonment are observed immediately after (renewal of heliophilous trees such as Pinus, decline of coprophilous fungi). This lapse of time is immediately followed by a well-known abrupt climate change, dated to ca. 5600 cal. BP (Magny et al., 2006). This change is not recorded by an increase of detrital input in Lake Aydat but pollen clearly attest to the development of a beech grove, characteristic of a cooler and wetter climate (de Beaulieu et al., 2006). A higher human pressure is recorded in the catchment by pollen and NPP data (fall of Fagus, increase of Poaceae and API) between ca. 4900-4600 cal. BP. This coincides with a high MS value denoting stronger detrital inputs. The latter that were favored by a higher erodibility of the soils subsequent to the change of vegetation, are also in agreement with previous work by Miras et al. (2004) which showed an important phase of fire-clearing at this period. The major flood event of the whole core is evidenced at ca. $3800 \mathrm{cal} \mathrm{BP}$. Its thickness $(6 \mathrm{~cm})$, reflecting 
its intensity, is unusual compared to the other ones. This event happened during a period of increasing human landscape management (ca. 3900-3500 cal BP). Indeed, a marked woodland opening is associated with an extension of grassland and heliophilous taxa during this period, also described in the neighbouring site of the Narse d'Espinasse (Miras et al., 2004). The rise of API is associated with a significant increase in dung-related fungi, especially Sporormiella, attesting to the local presence of animals (Davis and Shafer, 2006). This points to the highly probable role of anthropogenic activities as a trigger of this flooding event. Then, a lesser anthropogenic pressure (revealed by a decrease in anthropization indices and a renewal of the forests, ca. 3500-3200 cal. BP) on the catchment allowed us to better distinguish a climatic imprint during the last phase of higher detrital input.

Thus, from the beginning of the sedimentary record to the Final Bronze period, detrital input variations were already under the joint influence of climate and of human activities, the effects of the latter being indeed punctually perceptible from the Middle Neolithic (ca. 5900 cal. BP).

\subsection{Upper unit (1770 - 0 cal. BP): general overview}

MS variations in the upper unit enabled 6 phases of higher background detrital input to be distinguished, at ca. 1510-1210 cal. BP, ca. 1130-1000 cal. BP, ca. 950-670 cal. BP, ca. 620-500 cal. BP, ca. 430- 150 cal. BP, and ca. 90-50 cal. BP (Figure 6). The MS values reached during these events are 2-4 times higher than in the lower unit. These phases of high detrital input coincide neither with known periods of climatic variations, nor with general trends of level fluctuations in Western Central Europe (Figure 6; Magny et al., 2007; Magny, 2013). Conversely and strikingly, phases of lower detrital input occur when solar activity is low - such as during Wolf and Spörer (Delaygue and Bard, 2011) - that are supposedly 
characterized by enhanced erosional fluxes (Magny, 2004, 2013). This inconsistency prompted us to invoke other factors than climate to explain these particular variations in detrital input. It is worth noting that detrital input and the frequency of flooding events increase when palynological data attest to a global increasing trend of local human impact throughout the last two millennia, as discussed below (Figure 6). Otherwise, diatom blooms are encountered all along this unit, and they are sometimes highly prominent (Figures 3, 6). As already mentioned above, $\mathrm{HI}$ and OI values are most probably due to a mixture of terrestrial OM and diatoms. Along the whole core, as is generally observed (e.g. Disnar et al., 2011), TOC and HI remain correlated, whereas HI and OI are anticorrelated. Thus, the simultaneous variation in these different parameters delineates different sedimentation phases. The top of the mass wasting deposit, dated from ca. 1770 cal. BP, delimits the beginning of the upper unit. This period coincides with a phase of higher lake levels in the Alps and the Jura mountains (Magny, 2004). In the absence of other evidence, this suggests that the gravitary event might have been triggered by a rise in the level of Lake Aydat, leading to an increase in hydrostatic pressure on a substantial and unstale accumulation of sediments that provoked the destabilization of the latter at the front of the Veyre River delta, as suggested by a morphological anomaly on sub bottom acoustic profiles (Figure 2).

\subsubsection{0-1500 cal. BP}

MS and organic indices (HI, OI) are in the same range as in the lower unit and are thus highly comparable, apart from TOC that show lower values. On the contrary, pollen and NPP data support the beginning of continuous crop cultivation. Woodlands are also attested as in the neighbouring site of the Narse d'Espinasse where deforestation is dated from the

transition of the $2^{\text {nd }}$ Iron Age-Roman period (Miras et al., 2004). 


\subsubsection{0-1200 cal. BP}

During this first outstanding phase of detrital input (\#1, Figure 6), the background sedimentation increases sharply: when compared to previous periods, MS values are multiplied by 2 around 1500 cal. BP, and by 4 around $1250 \mathrm{cal}$. BP. This abrupt and definitive change in the detrital input pattern matches a marked decrease in solar activity (Wanner et al., 2008). Neither TOC nor HI or OI values undergo marked variations (TOC 5.5\%, HI 250

mgHC.g ${ }^{-1}$ TOC, OI $\sim 125 \mathrm{mgO}_{2} \cdot \mathrm{g}^{-1}$ TOC). Palynological data clearly evidence a sharp increase in the human pressure during this period. The drop in the AP/T ratio and the increase in herbaceous taxa values indicate large and repeated woodland openings associated to the extension of grasslands. The increase in API, crop pollen and a significant rise in coprophilous fungi prove the local presence of livestock in the surroundings of the lake, and attest to a land-use system that included crop cultivation. The end of this first phase of detrital input (at ca. 1200 cal. BP) is accompanied by the doubling of the sedimentation rate, which then reaches more than $5 \mathrm{~mm} / \mathrm{yr}$ (background sedimentation), a much greater value than that of the deeper parts of the sediment record. This change takes place at the end of a wetter period, in a context of high anthropogenic pressure. These two factors could have favored the development of primary productivity in the lake, as testified by the numerous diatom blooms observed from this period (the amount of which is sufficient to explain the doubling of the sedimentation rate; Figure 3) that could sign the beginning of the first eutrophication of the lake.

\subsubsection{0-150 cal. BP}


The beginning of this period (ca. 1200-1130 cal. BP) records a transitory but marked decrease in MS (<50.10 $0^{-5}$ S.I.) accompanied by an increase in TOC (up to ca. $\left.10 \%\right)$ and simultaneously in HI, with a coeval decrease in OI. Pollen and NPP do not record any substantial change in human pressure on the catchment, which remains globally high. However, the observation of the core reveals the pervasiveness of diatom blooms during this interval (Figure 3) that is confirmed by the rise in the TOC and HI values. Accordingly, this short period indicates the maximum of the eutrophication initiated from $1200 \mathrm{cal}$. BP, probably favoured by increased nutrient inputs linked to strong anthropogenic pressure and to more favorable climatic conditions (Hilfinger et al., 2001). This short primary period is followed by a transitory trend, leading to the outstanding detrital phase \#2, marked by a sharp decrease in TOC and HI values, and an increase in OI values (Figure 3). Then the stabilisation of TOC at around 4\%, of OI and HI at $160 \mathrm{mgO}_{2} \cdot \mathrm{g}^{-1} \mathrm{TOC}$ and $210 \mathrm{mgHC} \cdot \mathrm{g}^{-1}$ TOC, respectively, are observed, these values testifying to a more oxidized and biodegraded OM than before (Disnar et al., 2008). The mean MS value reaches ca. $75.10^{-5}$ S.I. Between ca. 1100 and $890 \mathrm{cal} \mathrm{BP}$, human occupation (mainly based on grazing and cereal cultivation) is signed by crop pollen values above $10 \%$, associated to moderate woodland clearances, confirming the maximum anthropogenic pressure reported by Miras et al. (2004) in the Espinasse peat marsh. The recording of more or less regularly spaced and thick flood deposits begins from this time period, underlining the probable role of human activities as triggers (at least partly) of such events. Four flood deposits are detected during the $9^{\text {th }}$ century, at the beginning of the $2^{\text {nd }}$ phase of detrital input (Figure 3). MS values decrease once more just after the detrital phase \#3 (Figure 6), during the Wolf solar minimum (680-600 cal. BP), together with higher HI and TOC, lower OI, and again with a dominance of diatom blooms. The latter are still associated to a slight decline in human activities, with a moderate renewal of tree taxa evidenced by the slight increase in the AP/T ratio. Comparably, another 
significant diatom bloom phase is observed between 500-450 cal. BP (between detrital phases \#4 and \#5), with the same consequences in terms of MS, and to a lesser extent of TOC, HI and OI. The greatest flood event frequency of the core is reached during the detrital phase \#5 ( 9 events during the XVIII ${ }^{\text {th }}$ century). The intensity of detrital input and the frequency of flood events do not decrease between 300-150 cal. BP. During this period, pollen and NPP data reveal the existence of a complex land-use system combining grazing and diversified cultures. Forestry is also in use as the AP/T ratio presents minimum values (ca 15\%), confirmed by historical sources (Georlette, 1957; Michelin, 1996). All this leads to an amplification of erosion and of detrital input, apparently independent of any climate forcing.

\subsubsection{0 cal. BP - present}

This last phase initially displays a similar trend in MS to the previous one, before an abrupt decrease in the signal intensity. This phase also differs from the previous ones by a significant increase in TOC (up to $6 \%$ in the most recent sediment), whereas OI reaches 125 $\mathrm{mgO}_{2} \cdot \mathrm{g}^{-1}$ TOC and HI $300 \mathrm{mgHC} \cdot \mathrm{g}^{-1}$ TOC. This indicates a substantial supply of OM that has still not suffered extensive alteration. These values are also comparable to those observed between ca. 1200-1130 cal. BP, and that were interpreted as indices of eutrophication of the lake. Considering that the lake is currently under this status, the shift of the considered parameters probably signs the change in trophic status of the lake, the beginning of which is dated from ca. $150 \mathrm{cal}$. BP in this hypothesis. Accordingly, a major landscape change is observed during this period with a renewal of tree dynamics - mainly pioneer trees such as Pinus which colonize abandoned areas. The regression of the main API and coprophilous fungi evidence locally a decrease in the anthropogenic pressure, which is well documented (Michelin, 1996). Crop cultivation is more affected than grazing activity. This new land-use 
system includes reforestation with exotic trees (Picea) that is observed since ca. the beginning of the $20^{\text {th }}$ century (Michelin, 1996).

\subsection{General discussion: drivers of environmental changes}

Thus, Lake Aydat sediments archive a succession of detrital phases of both climatic and anthropogenic origin:

- From 6730 to 3200 cal. BP, climate appears most of the time as the principal driver of detrital input. However, every occasional human occupation around the lake results in a well-marked increase in detrital input. For instance, the first punctual human activities in the catchment and the cooler and wetter climatic period at ca. 5900 cal. BP probably reinforce each other, entailing an intensification of detrital input.

- Then, the role of the climate on the evolution of the detrital input becomes less obvious as anthropogenic pressure increases. The latter reaches the threshold necessary to definitely disrupt the detrital input pattern: the major changes in land management initiated ca. 1500 cal. BP lead to the definitive change of this pattern.

- This is followed by (1) the doubling of the background sedimentation rate (ca. 1200 cal. $\mathrm{BP})$, caused by the increase in the occurrences of diatom blooms and most of all (2) by the appearance of recurrent and numerous flooding events from $1100 \mathrm{cal}$. BP, all of these features being certainly linked to the growing pressure of anthropogenic activities on the local environment.

Thus, through time, human activities have overtaken climate forcing and dictated a new sedimentary dynamics that still prevails. The periods of bloom predominance partially complicate the signal arising from the catchment. Consequently, MS records the catchment evolution, together with the autochthonous signal. What underlies the sharp transitions from 
blooms to intense detrital phases is not clearly established, but probably results from a threshold effect. The general trend of the last few centuries had also been previously observed in the sediments from the Pavin crater lake over the last 700 years (ca. $20 \mathrm{~km} \mathrm{SW} \mathrm{Aydat;}$ Stebich et al., 2005), which suggests an anthropogenic regional control on the lacustrine sedimentation dynamics. Comparison of the Aydat record with others in the area is much more difficult due to the lower temporal resolution of the previous studies (e.g. maar Lake Le Bouchet; Reille and de Beaulieu, 1988; Lake Chambon, Gay and Macaire, 1999; Sarlieve marsh, Macaire et al., 2010). This problem is not specific to the area studied here, since the majority of studies available on the Holocene climate, covering either the last centuries or millennia at a high resolution, or a multi-millenial scale at a low resolution, make any comparison with high-resolution sedimentary records on multi-millenial time scales difficult (Wanner et al., 2008).

\section{Conclusions}

The sedimentary sequence retrieved in Lake Aydat covers the last $6700 \mathrm{yrs}$, constitutes a high-resolution hydrologic record unique in the Massif Central and reflects the dynamics of a lake that is very sensitive to environmental changes. The particular morphology of the valley favored the development of a strongly dilated and high quality series. Low amplitude variations of detrital input until $1500 \mathrm{cal}$. BP are interpreted as mainly climatedriven and seem connected to solar activity. They are punctually interrupted by human-driven phases of higher detrital input. Later on the sedimentation is much more disturbed by human activities that induced, in a favorable climatic context, (i) recurrent flooding events since the Middle Ages (ca. $1100 \mathrm{cal}$. BP) and (ii) the doubling of the background sedimentation rate. Different phases of eutrophication of the lake were also distinguished. According to the 
sedimentary archive, the current one was probably initiated ca. 150 cal. BP. The strong anthropogenic imprint on the sedimentary record complicated its comparison with other palaeoclimatic records. But this multi-proxy study documents major environmental changes during the mid- and late-Holocene, and constitutes a remarkable example of agropastoral dynamics leading to a definitive change in the detrital input pattern of a lake.

\section{Acknowledgements}

We thank ARTEMIS program for AMS radiocarbon dating, B. Vannière and A. Stock (Chrono-Environnement, Besançon) for MS measurements, I. Billy (EPOC, Bordeaux, France) for XRF measurements, IPROS (Orléans, France) for density pictures, G. Ledoux and P. Lajeunesse (CEN Université Laval, Québec, Canada) for the seismic survey, B. Fanget and E. Malet for their help during the coring, and J. Granja, V. Janvier and A. Foucher for having contributed to the comprehension of the sedimentary infill, and the anonymous reviewers for their constructive comments.

\section{Funding}

This study was supported by the Erode project funded by the INSU/CNRS (Institut National des Sciences de l'Univers / Centre National de la Recherche Scientifique). M.L. also acknowledges the Région Centre for the attribution of a Ph.D grant.

\section{References}

Alfonso S (2000) Etude de paléoenvironnements littoraux. Contribution à l'établissement d'une échelle chronostratigraphique à partir des retombées atmosphériques de métaux lourds. Bordeaux (France): $\mathrm{PhD}$ thesis, University of Bordeaux 1.

Appleby PG (2000) Radiometric dating of sediment records in European mountain lakes. Journal of Limnology 59: $1-14$.

Ariztegui D, Chondrogianni C, Lami A, Guilizzoni P, Lafargue E (2001) Lacustrine organic matter and the Holocene paleoenvironmental record of Lake Albano (central Italy). Journal of Paleolimnology 26: 283 292.Arnaud F, Revel M, Chapron E, Desmet M, Tribovillard N (2005) 7200 years of Rhône river 
flooding activity in Lake Le Bourget, France: a high-resolution sediment record of NW Alps hydrology. The Holocene 15: 420-428.

Auriat S (1957) Etude des sondages et captages dans plusieurs coulées de la Chaîne des Puys (Balmet, Côme, Louchadières, Aydat, Tiretaine). Revue des sciences naturelles d'Auvergne 23: 97-141.

Ballut C, Michelin Y, Miras Y (2012) Landscape human shaping and spatial mobility of the agropastoral practices in the Chaine des Puys during the historical times (Massif Central, France). Quaternary International 251: 97-106.

Ballut C (2000) Evolution environnementale de la Limagne de Clermont-Ferrand au cours de la seconde moitié de l'Holocène. Limoges (France): PhD thesis, University of Limoges.

Battarbee RW, Bennion H (2011) Palaeolimnology and its developing role in assessing the history and extent of human impact on lake ecosystems. Journal of Paleolimnology 45: 399-404.

de Beaulieu JL, Andrieu-Ponel V, Cheddadi R, Guiter F, Ravazzi C, Reille M, Rossi S (2006) Apport des longues séquences lacustres à la connaissance des variations des climats et des paysages pléistocènes. Comptes-Rendus Palevol 5: 65-72.

de Beaulieu JL, Goeury C (1987) Zonation automatique appliquée à l'analyse pollinique : exemple de la narse d'Ampoix (Puy-de-Dôme). Bulletin de l'Association Française pour l'Etude du Quaternaire 24: 49-61.

Behre KE (1981) The interpretation of anthropogenic indicators in pollen diagrams. Pollen et Spores 23: 225245.

Boivin P, Besson JC, Briot D, Gourgaud A (2004) Volcanologie de la Chaîne des Puys (with map). Aydat (France): Parc Naturel Régional des Volcans d'Auvergne

Bouchet C (1987) Hydrogéologie en milieu volcanique. Le Bassin de la Veyre. Avignon (France): $\mathrm{PhD}$ thesis, University of Avignon.

Champion M (1858-1864) Les inondations en France du VIe siècle à nos jours. 4 tomes. Paris (France): Dunod.

Chapron E, Alberic P, Jezequel D, Versteeg W, Bourdier JL, Sitbon J (2010) Multidisciplinary characterisation of sedimentary processes in a recent maar lake (Lake Pavin, French Massif Central) and implication for natural hazards. Natural Hazards and Earth System Sciences 10: 1815-1827.

Chapron E, Desmet M, De Putter T, Loutre MF, Beck C, Deconinck JF (2002) Climatic variability in the northwestern Alps, France, as evidenced by 600 years of terrigenous sedimentation in Lake Le Bourget. The Holocene 12: 59-68.

Costanza R, Graumlich L, Steffen W, Crumley C, Dearing J, Kibbard K, Leemans R, Redman C, Schimel D (2007) Sustainability or collapse: what can we learn from integrating the history of humans and the rest of nature? Ambio 36: 522-527.

Crutzen PJ (2002) Geology of mankind. Nature 415: 23.

Danzeglocke U, Jöris O, Weninger B (2011) CalPal-2007online. http://www.calpal-online.de/, accessed 2011$10-05$.

Davis OK, Shafer DS (2006) Sporormiella fungal spores, a palynological means of detecting herbivore density. Palaeogeography, Palaeoclimatology, Palaeoecology 237: 40-50.

Dearing JA (2006) Climate-human-environment interactions: resolving our past. Climate of the Past 2: 187-203.

Deblaère JC, Fabry MH (1998) Inventaire des situations à precipitations remarquables en Auvergne, Bourgogne et Rhône-Alpes. Bron (France): Météo-France, Direction Interrégionale Centre-Est. 
Debret M, Chapron E, Desmet M, Rolland-Revel M, Magand O, Trentesaux A, Bout-Roumazeille V, Nomade J, Arnaud F (2010) Northwestern Alps Holocene paleohydrology recorded by flooding activity in Lake Le Bourget, France. Quaternary Science Reviews 29: 2185-2200.

Delaygue G, Bard E (2011) An Antarctic view of Beryllium-10 and solar activity for the past millennium. Climate Dynamics 36: 2201-2218.

Disnar JR, Stefanova M, Bréheret JG, Macaire JJ (2011) Microbial mat development and dolomite formation under pre-evaporitic conditions during the Atlantic in a temperate area: the Sarliève Lake (French Massif Central). Organic Geochemistry 42: 1089-1098.

Disnar JR, Jacob J, Morched-Issa M, Lottier N, Arnaud F (2008) Assessment of peat quality by molecular and bulk geochemical analysis; application to the Holocene record of the Chautagne marsh (Haute Savoie, France). Chemical Geology 254: 101-112.

Ejarque A, Miras Y, Riera S (2011) Pollen and non-pollen palynomorph indicators of vegetation and highland grazing activities obtained from modern surface and dung datasets in the eastern Pyrenees. Review of Palaeobotany and Palynology 167: 123-139.

Espitalié J, Derro G, Marquis F (1985) La pyrolyse Rock-Eval et ses applications. Revue de l'Institut français du Pétrole 40: 563-579.

Faegri K, Iversen J (1989) Textbook of Pollen Analysis. New York: John Wiley \& Sons.

Fourmont A, Macaire JJ, Bréheret JG (2009) Contrasted Late Glacial and Holocene hydrology of Sarlieve paleolake (France) from sediment geoetry and detrital versus biochemical composition. Journal of Paleolimnology 41: 471-490.

Gay I, Macaire JJ (1999) Estimation of Late Glacial and Holocene chemical erosion rates, Lake Chambon watershed, Massif Central, France. Comptes-rendus de l'Académie des Sciences, Série II, Fascicule A Sciences de la Terre et des Planètes 328: 387-392.

van Geel B, Coope GR, van der Hammen T (1989) Palaeoecology and stratigraphy of the Lateglacial type section at Usselo (The Netherlands). Review of Palaeobotany and Palynology 60: 25-129.

Genêt F (2007) Indomptable Loire. Mémoire des grandes crues. Digoin (France): JP Neuville.

Georlette R (1957) Quelques aspects de l'histoire des forêts françaises depuis la fin du moyen-âge jusqu'à la promulgation de l'Ordonnance de 1669. Revue Forestière Française 1957: 113-127.

Hilfinger MF, Mullins HT, Burnett A, Kirby ME (2001) A 2500 year sediment record from Fayetteville Green Lake, New York: evidence for anthropogenic impacts and historic isotope shifts. Journal of Paleolimnology 26: 293-305.

IPCC (2007) Contribution of Working Groups I, II and III to the Fourth Assessment Report of the Intergovernmental Panel on Climate Change. Geneva (Switzerland): IPCC.

Juvigné E, Milcamps V, Evin J, Delibrias G (1988) Ages de traits polliniques et chronozonation du Tardiglaciaire et de l'Holocène dans le Massif Central (France). Mededelingen - Rijks Geologische Dienst 42: 120-142.

Lafargue E, Marquis F, Pillot D (1998) Rock-Eval 6 applications in hydrocarbon exploration, production, and soil contamination studies. Revue de l'Institut Français du Pétrole 53: 421-437. 
Leroux A, Bichet V, Walter-Simonnet AV, Magny M, Adatte T, Gauthier E, Richard H, Baltzer A (2008) Late Glacial-Holocene sequence of Lake Saint-Point (Jura Mountains, France): Detrital inputs as records of climate change and anthropic impact. Comptes-Rendus Geosciences 340: 883-892.

Macaire JJ, Fourmont A, Argant J, Bréheret JG, Hinschberger F, Trément F (2010) Quantitative analysis of climate versus human impact on sediment yield since the Lateglacial: The Sarliève palaeolake catchment (France). The Holocene 20: 4, 497-516.

Macaire JJ, Bossuet G, Choquier A, Cocirta C, De Luca P, Dupis A, Gay I, Mathey E, Guenet P (1995) Effets climatiques et anthropiques sur l'érosion mécanique en montagne cristalline de région tempérée pendant le Tardiglaciaire et l'Holocène. Un exemple, le bassin du Lac Chambon (Massif Central, France). Comptes Rendus de l'Académie des Sciences, série II a 320: 579-585.

Magny M, de Beaulieu JL, Drescher-Schneider R, Vannière B, Walter-Simonnet AV, Miras Y, Millet L, Bossuet G, Peyron O, Brugiapaglia E, Leroux A (2007) Holocene climate changes in the central Mediterranean as recorded by lake-level fluctuations at Lake Accesa (Tuscany, Italy). Quaternary Science Reviews 26: 1736-1758.

Magny M, Leuzinger U, Bortenschlager S, Haas JN (2006) Tripartite climate reversal in Central Europe 56005300 years ago. Quaternary Research 65: 3-19.

Magny M (2013) Orbital, ice-sheet, and possible solar forcing of Holocene lake-level fluctuations in west-central Europe. A comment on Bleicher (2013) The Holocene, HOL-12-0184.R1

Magny M (2004) Holocene climate variability as reflected by mid-European lake-level fluctuations and its probable impact on prehistoric human settlements. Quaternary International 113: 65-79.

Meyers PA, Lallier-Vergès E (1999) Lacustrine sedimentary organic matter records of Late Quaternary paleoclimates. Journal of Paleolimnology 21: 345-372.

Michard G, Sarazin G, Jézéquel D, Albéric P, Ogier S (2001) Annual budget of chemical elements in a eutrophic lake, Lake Aydat (Puy-de-Dôme), France. Hydrobiologia 459: 27-46.

Michelin Y, Vergne V, Cougoul C, Cournut S (2001) Variations des teneurs en éléments minéraux dans un basmarais holocène : la Vezolle (Chaîne des Puys), premières recherches des manifestations anthropiques.

Quaternaire 1-2: 31-41.

Michelin Y (1996) Les jardins de Vulcain. Paysages d'hier, d'aujourd'hui et de demain dans la chaîne des Puys du Massif Central français. Paris: Editions de la Maison des Sciences de l'Homme.

M iras Y (2009) L'étude des relations entre végétation et pluie pollinique actuelle sur le plateau de Millevaches (Limousin, France) : outil pour une meilleure caractérisation pollenanalytique des formes paysagères et des pratiques agrosylvopastorales. Revue des Sciences Naturelles d'Auvergne 73: 71-105.

Miras Y, Laggoun-Défarge F, Guenet P, Richard H (2004) Multi-disciplinary approach to changes in agropastoral activities since the Sub-Boreal in the surroundings of the "narse d'Espinasse" (Puy de Dôme, French Massif Central). Vegetation History and Archaeobotany 13: 91-103.

Mulder T, Chapron E (2011) Flood deposits in continental and marine environments: Character and significance. Sediment transfer from shelf to deep water - Revisiting the delivery system: AAPG Studies in Geology 61: $1-30$.

Mulder T, Cochonat P (1996) Classification of offshore mass movements. Journal of Sedimentary Research 66: 43-57. 
Ogier S, Disnar JR, Albéric P, Bourdier G (2001) Neutral carbohydrate geochemistry of particulate material (trap and core sediments) in an eutrophic lake (Aydat, France). Organic Geochemistry 32: 151-162.

Ogier S (1999) Diagenèse précoce en domaine lacustre : étude des composés minéraux et organiques des sédiments récents du lac d'Aydat (Puy de Dôme, France). Orléans (France): $\mathrm{PhD}$ thesis, University of Orléans.

Prat B (2006) Systèmes agropastoraux et milieux périurbains en Basse Auvergne au cours des trois derniers millénaires : contribution de l'analyse palynologique à l'étude des interactions sociétés-milieux. Clermont-Ferrand (France): PhD thesis, University Blaise-Pascal.

Reille M, de Beaulieu JL (1988) History of the Würm and Holocene vegetation in western velay (Massif Central, France): A comparison of pollen analysis from three corings at Lac du Bouchet. Review of Palaeobotany and Palynology 54: 233-248.

Reyss JL, Schmidt S, Legeleux F, Bonté P (1995) Large, low background well-type detectors for measurements of environmental radioactivity. Nuclear Instruments and Methods in Physics Research Section A: Accelerators, Spectrometers, Detectors and Associated Equipment 357: 391-397.

Sarazin G, Gaillard JF, Philippe L, Rabouille C (1995) Organic matter mineralization in the pore water of a eutrophic lake (Lake Aydat, Puy de Dôme, France). Hydrobiologia 315: 95-118.

Sarazin G, Michard G, Al Gharib I, Bernat M (1992) Sedimentation rate and early diagenesis of particulate organic nitrogen and carbon in Lake Aydat (Puy-de-Dôme, France). Chemical Geology 98: 307-316.

Sarazin G, Devaux J (1991) Diagenèse précoce de la matière organique dans la colonne d'eau et le sédiment d'un lac eutrophe : le lac d'Aydat (Puy-de-Dôme). Oceanis 17: 533-560.

Stebich M, Brüchmann C, Kulbe T, Negendank JFW (2005) Vegetation history, human impact and climate change during the last 700 years recorded in annually laminated sediments of Lac Pavin, France. Review of Palaeobotany and Palynology 133: 115-133.

Stefanova M, Disnar JR (2000) Composition and early diagenesis of fatty acids in lacustrine sediments, lake Aydat (France). Organic Geochemistry 31: 41-55.

Surmely F, Miras Y, Guenet P, Nicolas V, Savignat A, Vannière B, Walter-Simonnet AV, Servera G, Tzortzis S (2009) Occupation and land-use history of a medium mountain from the Mid-Holocene: A multidisciplinary study performed in the South Cantal (French Massif Central). Comptes-Rendus Paleovol 8: 737-748.

Wanner H, Beer J, Bütikofer J, Crowley TJ, Cubasch U, Flückiger J, Goosse H, Grosjean M, Joos F, Kaplan JO, Küttel M, Müller SA, Prentice IC, Solomina O, Stocker TF, Tarasov P, Wagner M, Widmann M (2008) Mid- to Late Holocene climate change: an overview. Quaternary Science Reviews 27: 1791-1828.

Wilkinson BH (2005) Humans as geologic agents: A deep-time perspective. Geology 33: 161-164.

Zolitschka B, Ariztegui D (2007) Lacustrine and marine archives of environmental variability across South America. Quaternary International 161: 1-3. 

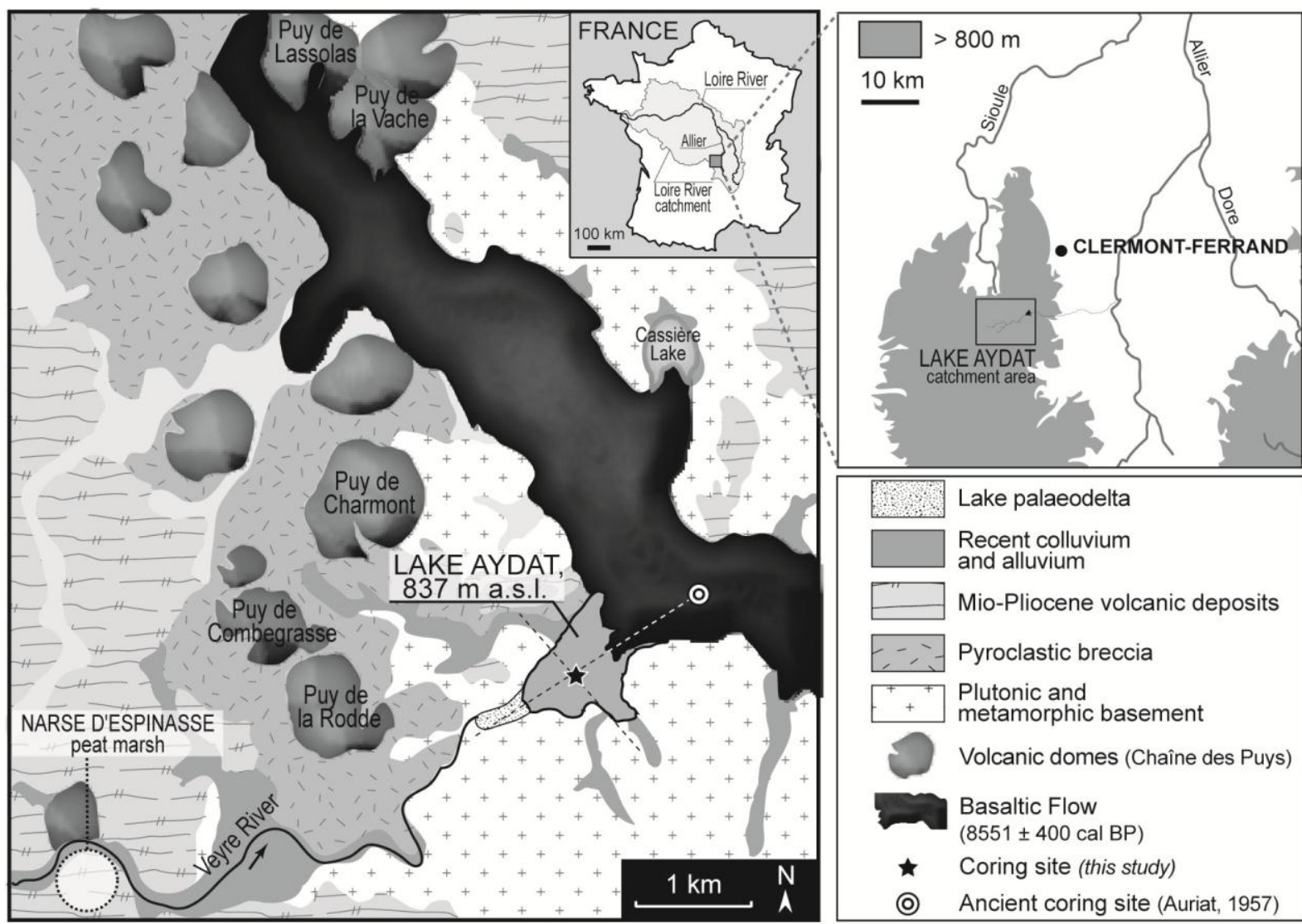

Figure 1: Location of Lake Aydat and its geological setting (after Boivin et al., 2004). Dashed lines locate topographic profiles presented in Fig. 2. 

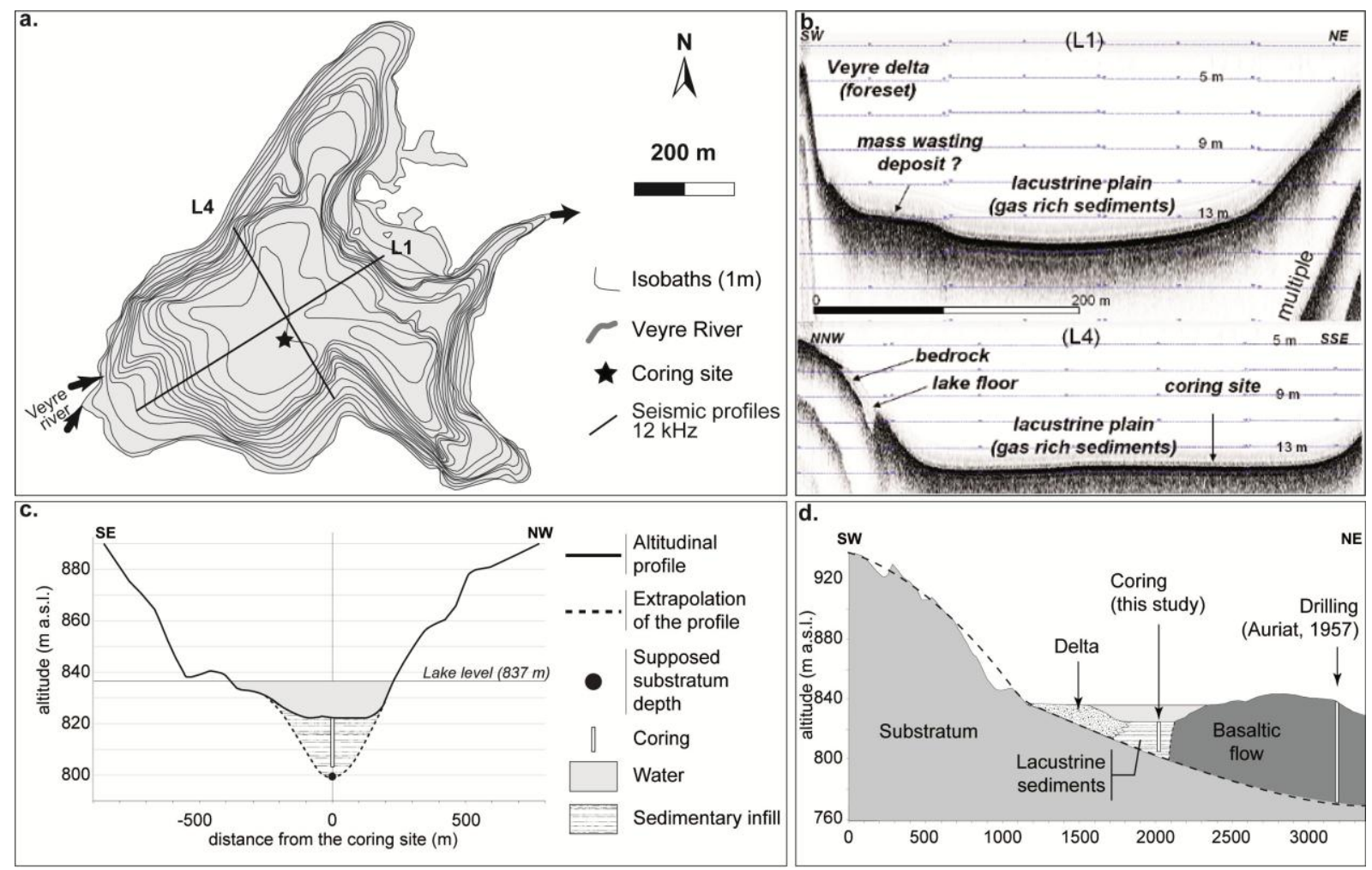

Figure 2: (a) Bathymetric map of Lake Aydat and location of the coring site and of the seismic profiles shown in (b). (c): Altitudinal profile transverse to the lake and extrapolation showing the morphology of the valley (location: see Fig. 1). (d): Schematic representation of a longitudinal profile, from the palaeodelta to the coring in the basaltic flow. Dashed line: approximate outline of the supposed location of the substratum of the lake, estimated from the river profile tendency. 


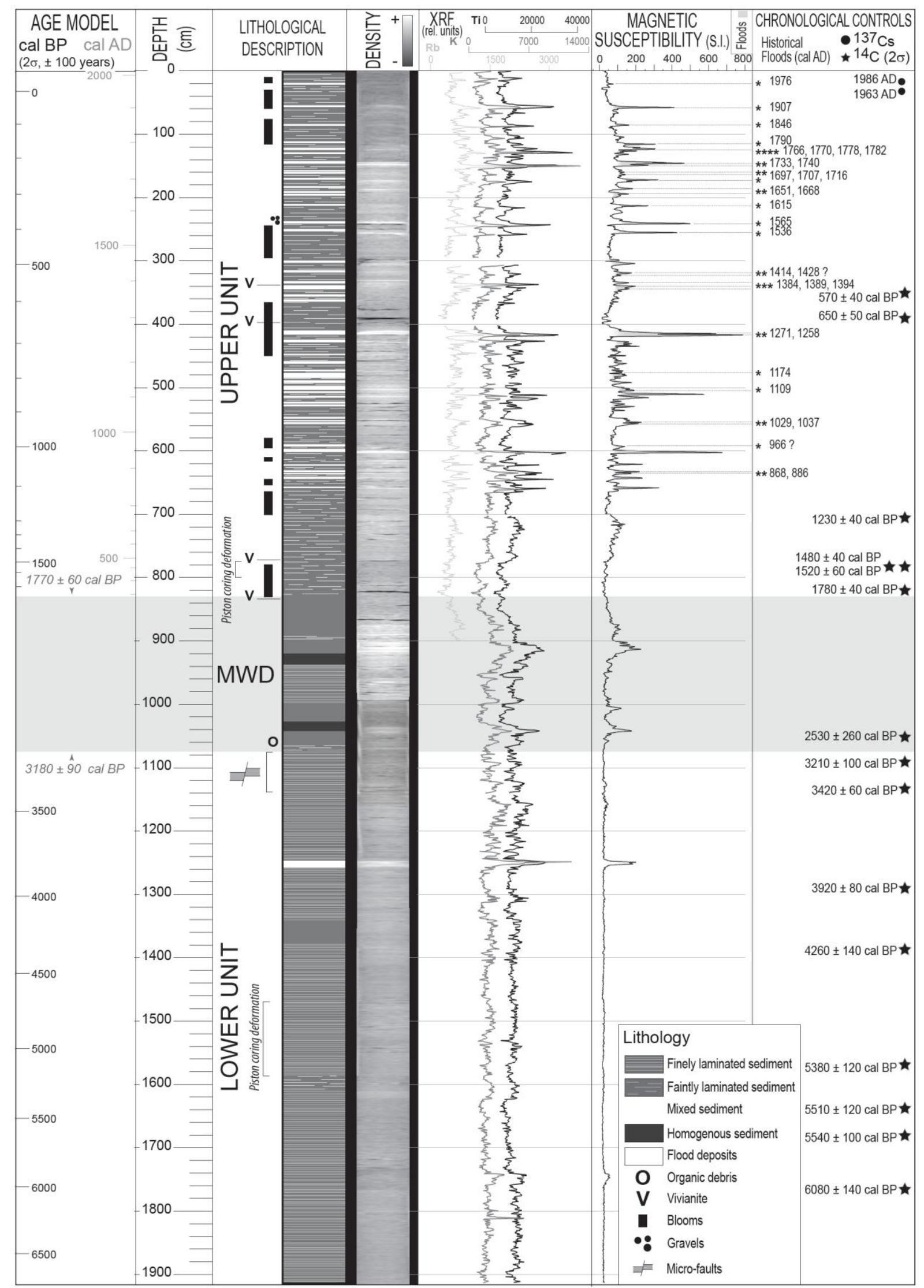

Figure 3: Core description, lithology and physical parameters (density, MS, and XRF - Rb, $\mathrm{Ti}, \mathrm{K})$, stratigraphic location of the ${ }^{137} \mathrm{Cs}$ and ${ }^{14} \mathrm{C}$ ages and of the historical floods. Mass 
wasting deposit (MWD) is presented as it appears in one of the two twin cores. Only the noteworthy diatom blooms are figured.

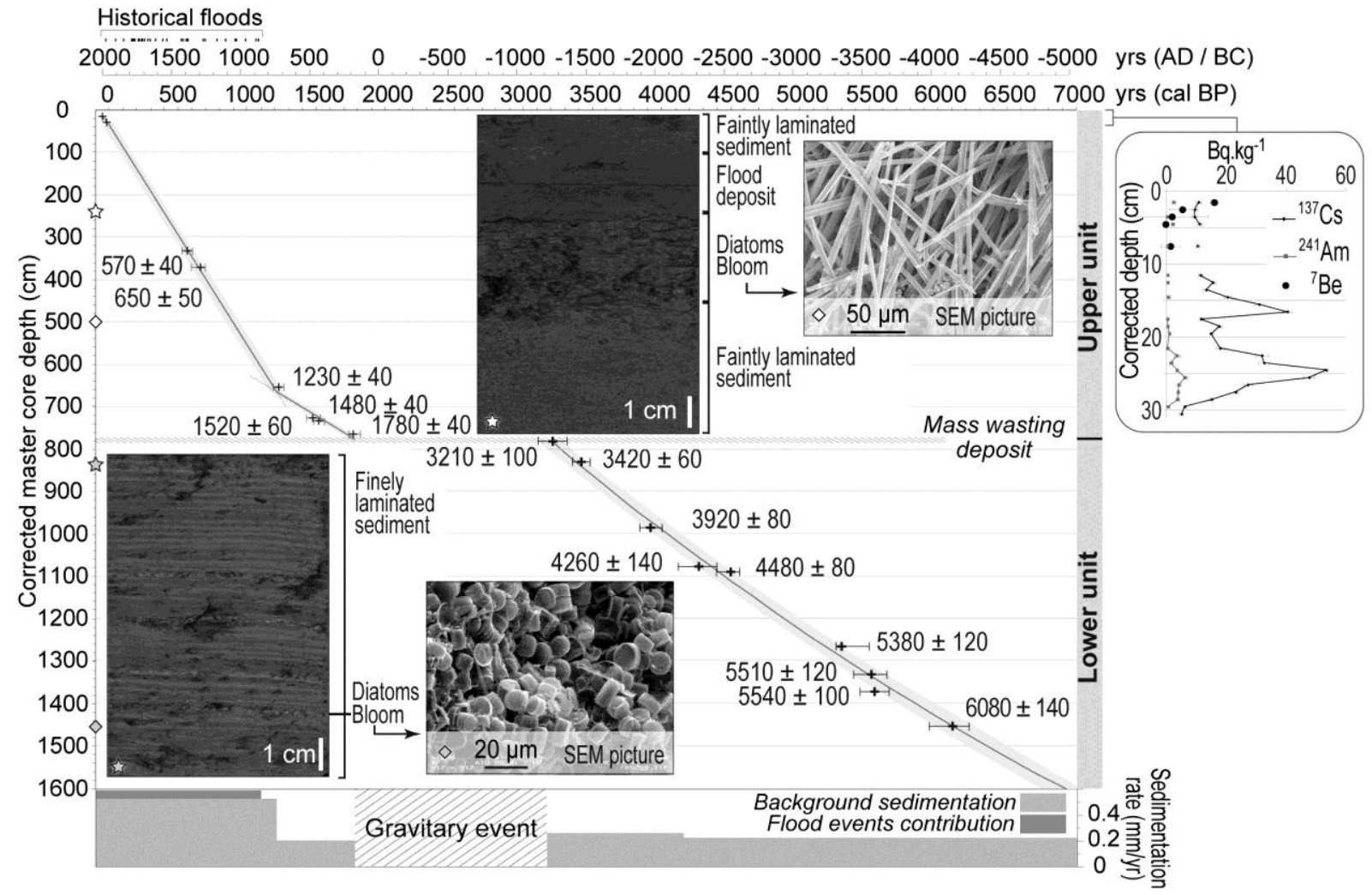

Figure 4: Age-depth model, correlation with historical floods, sedimentation rates and sedimentological units. Stars and diamonds locate the depths of the pictures presented. ${ }^{137} \mathrm{Cs}$, ${ }^{241} \mathrm{Am}$ and ${ }^{7} \mathrm{Be}$ of the top of the core are provided on the right. 


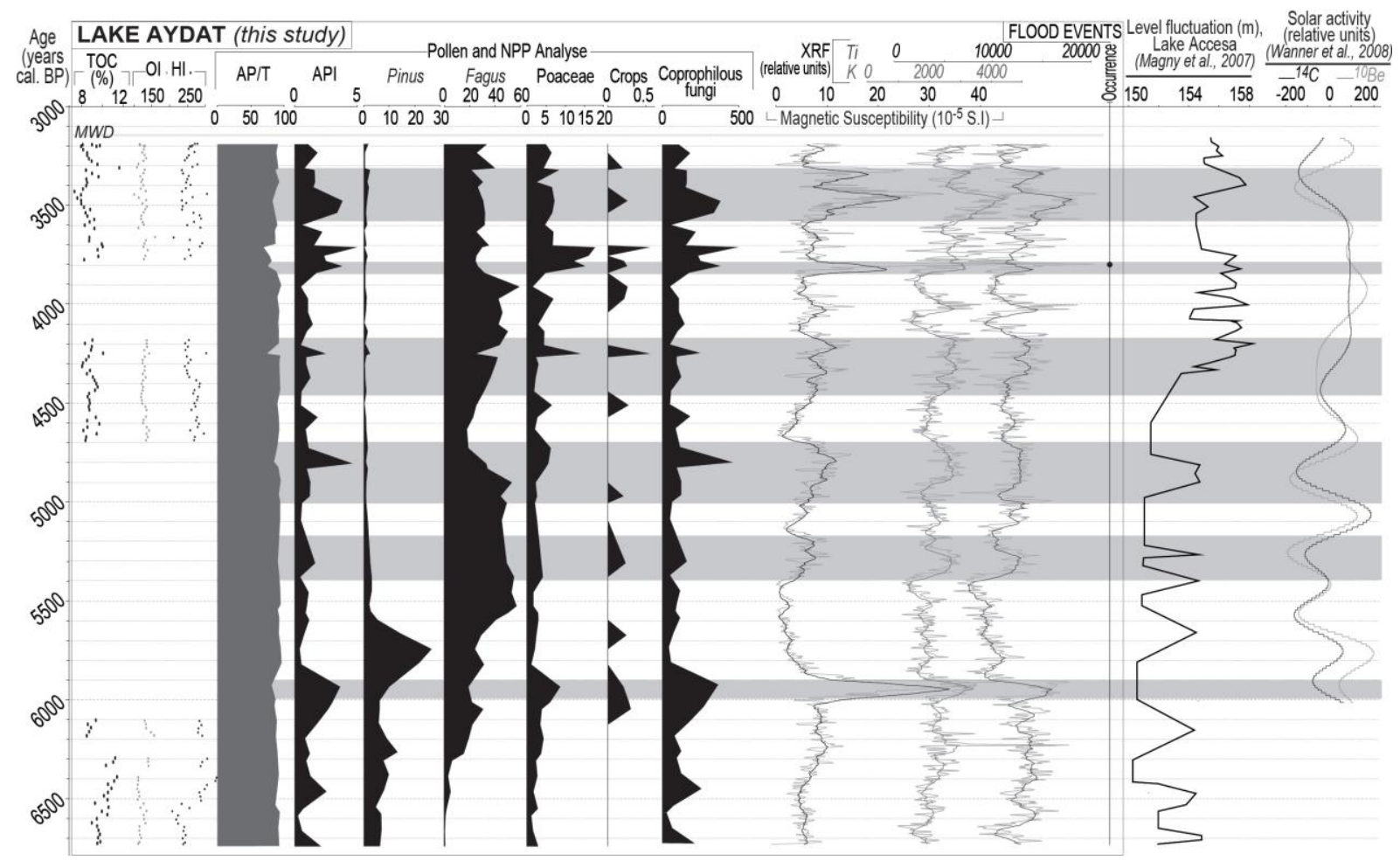

Figure 5: Background signal of the lower unit - MS, TOC, OI, HI, pollen and NPP analyses, compared to solar activity (Wanner et al., 2008) and Lake Accesa level fluctuations (Magny et al., 2007). Phases of higher detritism are indicated by the horizontal grey strips. MWD: mass wasting deposit.

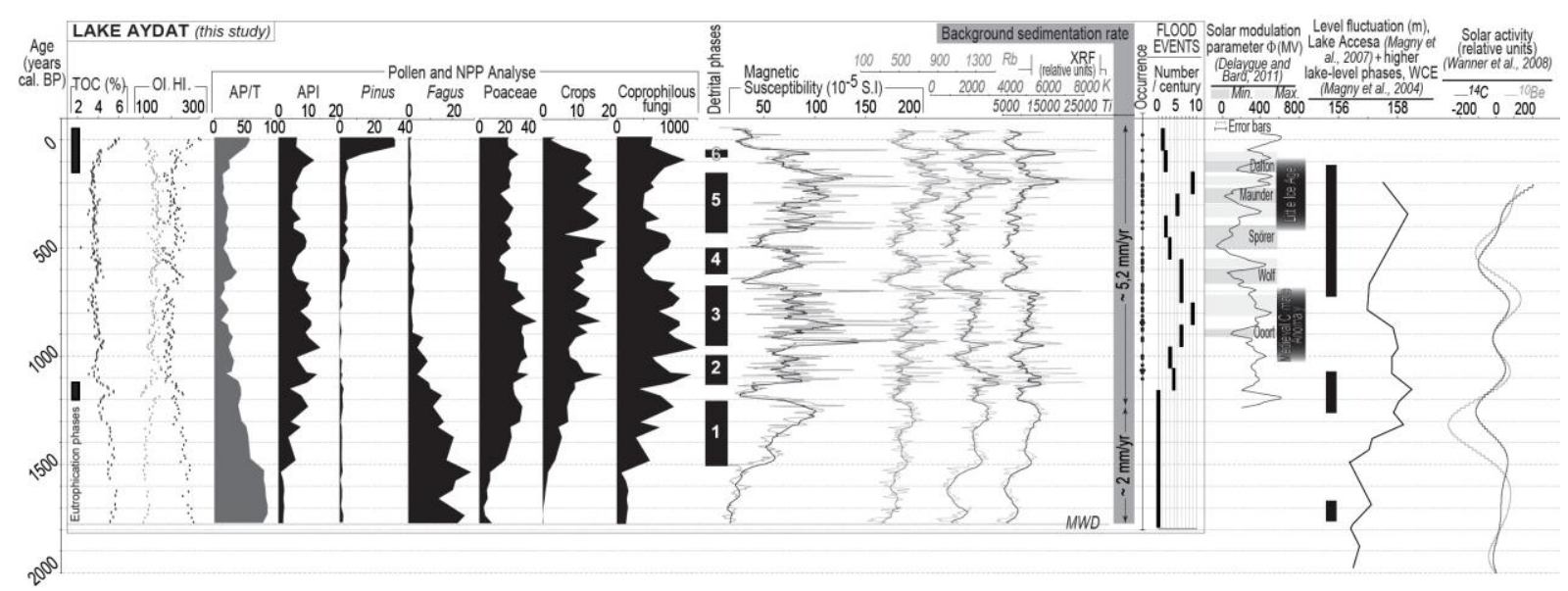

Figure 6: Background signal of the upper unit - MS, TOC, OI, HI, pollen and NPP analyses, occurrence and frequency of flood events and eutrophication phases compared to WestCentral European (WCE) lake-level records (Magny, 2004), Lake Accesa level fluctuations 
(Magny et al., 2007), and solar activity (Delaygue and Bard, 2011; Wanner et al., 2008). MWD: mass wasting deposit. 
Table I: AMS radiocarbon dates and ${ }^{137}$ Cs results obtained from the Lake Aydat core.

\begin{tabular}{|c|c|c|c|c|c|c|c|c|}
\hline \multirow{2}{*}{$\begin{array}{l}\text { Datation } \\
\text { method }\end{array}$} & \multirow{2}{*}{$\begin{array}{l}\text { Type of } \\
\text { material }\end{array}$} & \multicolumn{2}{|c|}{$\begin{array}{l}\text { Master core } \\
\text { depth }(\mathrm{cm})\end{array}$} & \multirow{2}{*}{\multicolumn{2}{|c|}{$\begin{array}{l}\text { Radiocarbon } \\
\text { age (BP) }\end{array}$}} & \multirow{2}{*}{ 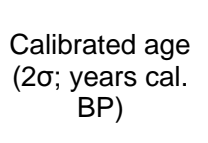 } & \multirow{2}{*}{$\begin{array}{l}\text { Laboratory } \\
\text { Name }\end{array}$} & \\
\hline & & Uncorrected & Corrected & & & & & \\
\hline${ }^{137} \mathrm{Cs}$ & $\begin{array}{c}\text { Bulk } \\
\text { sediment }\end{array}$ & 16.5 & 16.5 & & - & - 36 (1986 AD) & - & \\
\hline${ }^{137} \mathrm{Cs}$ & $\begin{array}{c}\text { Bulk } \\
\text { sediment }\end{array}$ & 25.5 & 24.5 & & - & - $13(1963$ AD) & - & \\
\hline${ }^{14} \mathrm{C}$ & Twig & 349.7 & 332.7 & 520 & \pm 30 & $570 \pm 40$ & SacA 21687 & \\
\hline${ }^{14} \mathrm{C}$ & Twig & 387.7 & 370.7 & 700 & \pm 30 & $650 \pm 50$ & SacA 21688 & \\
\hline${ }^{14} \mathrm{C}$ & Twig & 467.5 & 433.2 & 1330 & \pm 30 & $1270 \pm 80$ & SacA 16355 & Excluded (reworked debris) \\
\hline${ }^{14} \mathrm{C}$ & Twig & 705.8 & 656.8 & 1265 & \pm 30 & $1230 \pm 40$ & SacA 21685 & \\
\hline${ }^{14} \mathrm{C}$ & Twig & 782.1 & 727.5 & 1575 & \pm 30 & $1480 \pm 40$ & SacA 21686 & \\
\hline${ }^{14} \mathrm{C}$ & Twig & 790.1 & 735.5 & 1630 & \pm 30 & $1520 \pm 60$ & SacA 21689 & \\
\hline${ }^{14} \mathrm{C}$ & Leaf & 820.3 & 766.5 & 1825 & \pm 30 & $1780 \pm 40$ & SacA 21690 & \\
\hline${ }^{14} \mathrm{C}$ & Leaf & 1056 & - & 2440 & \pm 30 & $2530 \pm 260$ & SacA 16356 & Excluded (intermediate unit) \\
\hline${ }^{14} \mathrm{C}$ & Charcoal & 1094.2 & 780.5 & 3005 & \pm 30 & $3210 \pm 100$ & SacA 16357 & \\
\hline${ }^{14} \mathrm{C}$ & Leaf & 1136.5 & 823.5 & 3190 & \pm 30 & $3420 \pm 60$ & SacA 16362 & \\
\hline${ }^{14} \mathrm{C}$ & Leaf & 1297.2 & 979.5 & 3605 & \pm 30 & $3920 \pm 80$ & SacA 16363 & \\
\hline${ }^{14} \mathrm{C}$ & Leaf & 1389.2 & 1071.5 & 3840 & \pm 30 & $4260 \pm 140$ & SacA 16364 & \\
\hline${ }^{14} \mathrm{C}$ & Twig & 1401.2 & 1083.5 & 4000 & \pm 30 & $4480 \pm 80$ & SacA 16358 & \\
\hline${ }^{14} \mathrm{C}$ & Seed (?) & $1576 \pm 5$ & $1258.7 \pm 5$ & 4615 & \pm 30 & $5380 \pm 120$ & SacA 16365 & \\
\hline${ }^{14} \mathrm{C}$ & Leaf & 1644.7 & 1327.5 & 4750 & \pm 30 & $5510 \pm 120$ & SacA 16359 & \\
\hline${ }^{14} \mathrm{C}$ & Leaf (?) & 1685.2 & 1368 & 4800 & \pm 35 & $5540 \pm 100$ & SacA 16360 & \\
\hline${ }^{14} \mathrm{C}$ & Twig & 1767.7 & 1449.5 & 5280 & \pm 30 & $6080 \pm 140$ & SacA 16366 & \\
\hline
\end{tabular}




\begin{tabular}{|c|c|c|c|c|c|c|c|c|c|c|c|}
\hline \multirow{2}{*}{$\begin{array}{c}\text { Event } \\
\text { nr }\end{array}$} & \multirow{2}{*}{$\begin{array}{l}\text { Master core } \\
\text { depth }(\mathrm{cm})\end{array}$} & \multicolumn{3}{|c|}{ Depth-Age model } & \multirow{2}{*}{$\begin{array}{l}\text { Historical } \\
\text { flood } \\
\text { events }\end{array}$} & \multirow{2}{*}{$\begin{array}{c}\text { Event } \\
\mathrm{nr}\end{array}$} & \multirow{2}{*}{$\begin{array}{l}\text { Master core } \\
\text { depth }(\mathrm{cm})\end{array}$} & \multicolumn{3}{|c|}{ Depth-Age model } & \multirow{2}{*}{$\begin{array}{c}\text { Historical } \\
\text { flood } \\
\text { events }\end{array}$} \\
\hline & & Age AD & Age cal. BP & Uncertainty & & & & Age AD & Age cal. BP & Uncertainty & \\
\hline$\# 1$ & $21-22$ & 1973 & -23 & 5 & 1976 & \# 29 & $409-410$ & 1280 & 670 & 50 & - \\
\hline$\# 2$ & $58-59$ & 1900 & 50 & 40 & 1907 & \# 30 & $412-416$ & 1275 & 675 & 50 & - \\
\hline \# 3 & $85-87$ & 1849 & 101 & 40 & 1846 & \# 31 & $416-420$ & 1273 & 677 & 50 & 1271 \\
\hline$\# 4$ & $116-117$ & 1791 & 159 & 40 & 1790 & \# 32 & $428-430$ & 1257 & 693 & 50 & 1258 \\
\hline \# 5 & $121-122$ & 1782 & 168 & 40 & 1782 & \# 33 & $435-436$ & 1245 & 705 & 50 & - \\
\hline \# 6 & $123-125$ & 1778 & 172 & 40 & 1778 & \# 34 & $450-451$ & 1216 & 734 & 50 & - \\
\hline$\# 7$ & $127-128$ & 1772 & 178 & 40 & 1770 & \# 35 & $462-463$ & 1193 & 757 & 50 & - \\
\hline \# 8 & $132-133$ & 1763 & 187 & 40 & 1766 & \# 36 & $474-475$ & 1171 & 779 & 50 & 1174 \\
\hline$\# 9$ & $144-148$ & 1740 & 210 & 40 & 1740 & \# 37 & $479-480$ & 1161 & 789 & 50 & - \\
\hline \# 10 & $149-150$ & 1736 & 214 & 40 & 1733 & \# 38 & $481-482$ & 1157 & 793 & 50 & - \\
\hline \# 11 & $160-161$ & 1715 & 235 & 40 & 1716 & \# 39 & $492-493$ & 1136 & 814 & 50 & - \\
\hline \# 12 & $164-165$ & 1707 & 243 & 40 & 1707 & $\# 40$ & $502-503$ & 1117 & 833 & 50 & - \\
\hline \# 13 & $172-174$ & 1692 & 258 & 40 & 1697 & \# 41 & $504-505$ & 1113 & 837 & 50 & 1109 \\
\hline \# 14 & $175-176$ & 1688 & 262 & 40 & - & \# 42 & $509-511$ & 1104 & 846 & 50 & - \\
\hline \# 15 & $186-187$ & 1667 & 283 & 40 & 1668 & \# 43 & $511-513$ & 1102 & 848 & 50 & - \\
\hline \# 16 & $195-196$ & 1651 & 299 & 40 & 1651 & \# 44 & $515-517$ & 1096 & 854 & 50 & - \\
\hline \# 17 & 214-215 & 1615 & 335 & 40 & 1615 & \# 45 & $526-527$ & 1077 & 873 & 50 & - \\
\hline \# 18 & $240-243$ & 1565 & 385 & 40 & 1565 & \# 46 & $530-531$ & 1069 & 881 & 50 & - \\
\hline \# 19 & $256-258$ & 1538 & 412 & 40 & 1536 & \# 47 & $549-550$ & 1034 & 916 & 50 & 1037 \\
\hline \# 20 & $303-306$ & 1449 & 501 & 40 & - & \# 48 & $552-553$ & 1028 & 922 & 50 & 1029 \\
\hline \# 21 & $319-321$ & 1422 & 528 & 40 & $1428 ?$ & \# 49 & $557-558$ & 1020 & 930 & 50 & - \\
\hline \# 22 & $323-324$ & 1416 & 534 & 40 & 1414 & \# 50 & $593-594$ & 952 & 998 & 50 & $966 ?$ \\
\hline \# 23 & $334,5-336,5$ & 1395 & 555 & 40 & 1394 & \# 51 & $600-605$ & 939 & 1011 & 50 & - \\
\hline \# 24 & $340-343$ & 1388 & 562 & 40 & 1389 & \# 52 & $621-622$ & 906 & 1044 & 50 & - \\
\hline \# 25 & $344-346$ & 1384 & 566 & 40 & 1384 & \# 53 & $633-634$ & 885 & 1065 & 50 & 886 \\
\hline \# 26 & $348-349$ & 1378 & 572 & 40 & - & \# 54 & $635-637$ & 882 & 1068 & 50 & - \\
\hline \# 27 & $359-360$ & 1357 & 593 & 50 & - & \# 55 & $642-644$ & 870 & 1080 & 50 & 868 \\
\hline \# 28 & $365-366$ & 1345 & 605 & 50 & - & \# 56 & $658-659$ & 843 & 1107 & 50 & - \\
\hline
\end{tabular}

